\title{
Microbispora corallina sp. nov., a new species of the genus Microbispora isolated from Thai soil
}

\author{
Yuki Nakajima, ${ }^{1}$ Vichien Kitpreechavanich, ${ }^{2}$ Ken-ichiro Suzuki ${ }^{1}$ \\ and Takuji Kudo'
}

Author for correspondence: Takuji Kudo. Tel: +8148462 1111. Fax: +81484624617. e-mail: kudo@jcm.riken.go.jp

1 Japan Collection of Microorganisms, The Institute of Physical and Chemical Research (RIKEN), Wako, Saitama 351-0198, Japan

2 Department of Microbiology, Faculty of Science, Kasetsart University, Chatuchak, Bangkok 10900, Thailand

\begin{abstract}
Two actinomycete strains, DF-28 and DF- $32^{\top}$, were isolated from soil samples collected in a deciduous dipterocarp forest in Thailand. They produced longitudinally paired spores on the tips of short sporophores alternately branched from aerial hyphae, and the chemotaxonomic properties of the isolates were the same as those of members of the family Streptosporangiaceae. These phenotypic properties, together with the results of a phylogenetic analysis based on 165 rRNA gene sequences, indicated that these isolates should be assigned to the genus Microbispora. The two isolates showed more than $93 \%$ DNA relatedness to each other, but their relatedness to any previously described species of the genus Microbispora was only $45 \%$ or less. They were distinguishable from previously described Microbispora spp. by a combination of physiological and biochemical properties. Therefore, a new species is proposed for these strains, under the name Microbispora corallina sp. nov. The type strain is strain DF-32 ${ }^{\top}$ ( = JCM 10267').
\end{abstract}

Keywords: Microbispora corallina sp. nov., Streptosporangiaceae, Actinomycetales, Actinobacteria, actinomycetes

\section{INTRODUCTION}

The genus Microbispora was proposed by Nonomura \& Ohara (1957) for an actinomycete strain producing longitudinally paired spores on aerial mycelia. In the Approved Lists of Bacterial Names (Skerman et al., 1980), 10 species were cited as members of the genus Microbispora; later, three others, Microbispora viridis (Miyadoh et al., 1985), Microbispora karnatakensis and Microbispora indica (Rao et al., 1987), were validly proposed as new species. Subsequently, this genus was well defined from a chemotaxonomic point of view, and Kroppenstedt et al. (1990) and Miyadoh et al. (1990) transferred Microbispora echinospora and $M$. viridis to the genus Actinomadura as Actinomadura echinospora and Actinomadura rugatobispora, respectively. On the basis of DNA-DNA hybridization experiments, Miyadoh et al. (1990) also proposed that

Abbreviation: $A_{2} p m, 2,6$-diaminopimelic acid.

The GenBank/EMBL/DDBJ accession number for the 165 rDNA sequence of Microbispora corallina DF-32 $\left(=\right.$ JCM $\left.10267^{\top}\right)$ is AB018046.
10 of the remaining species (with the exception of Microbispora bispora) should be combined into the type species Microbispora rosea with two subspecies, $M$. rosea subsp. rosea and $M$. rosea subsp. aerata. Analysis of $16 \mathrm{~S}$ rDNA sequences by Wang et al. (1996b) indicated that M. bispora was phylogenetically distant from the $M$. rosea cluster and other members of the family Streptosporangiaceae, and this species was transferred to the new genus Thermobispora (as Thermobispora bispora). Recently, Zhang et al. (1998) reclassified the genus Thermomonospora and proposed the transfer of Thermomonospora mesophila, which produces spores singly borne on aerial hyphae, to the amended genus Microbispora (as Microbispora mesophila).

While searching for novel actinomycetes from tropical regions of South-East Asia, we isolated two strains (DF-28 and DF-32 ${ }^{\mathrm{T}}$, from soil samples collected in Thailand) showing typical morphological characteristics of the genus Microbispora. In this paper we report the taxonomic characterization and classification of these isolates and propose a new species, Microbispora corallina sp. nov., for the strains. 


\section{METHODS}

Bacterial strains. Strains DF-28 and DF- $32^{\mathrm{T}}$ were isolated from soil samples collected in a deciduous dipterocarp forest in Thailand by means of the dilution-agar plating method with humic acid/vitamin agar (Hayakawa \& Nonomura, 1987). The following type strains of the named species belonging to the redefined genus Microbispora were used for the comparative studies: $M$. rosea subsp. rosea JCM $3006^{\mathrm{T}}$, JCM 3021 (formerly the type strain of Microbispora amethystogenes), JCM 3022 (formerly the type strain of Microbispora chromogenes), JCM 3023 (formerly the type strain of Microbispora diastatica), JCM 3024 (formerly the type strain of Microbispora parva), JCM 8971 (formerly the type strain of $M$. indica), JCM 8972 (formerly the type strain of $M$. karnatakensis), $M$. rosea subsp. aerata JCM $3076^{\mathrm{T}}$ (formerly the type strain of Microbispora aerata), JCM 3110 (formerly the type strain of Microbispora thermodiastatica) and JCM 3111 (formerly the type strain of Microbispora thermorosea). ' $M$. rosea subsp. nonnitritogenes' JCM 3298 and ' $M$. amethystogenes subsp. nonreducans' JCM 10122, which do not have standing in nomenclature were also used for reference.

Morphology. Strains DF-28 and DF-32 ${ }^{\mathrm{T}}$ were grown for 2 weeks at $28{ }^{\circ} \mathrm{C}$ on oatmeal agar supplemented with $1 \%$ $(\mathrm{w} / \mathrm{v})$ yeast extract and inorganic salts/starch agar supplemented with $1 \%(\mathrm{w} / \mathrm{v})$ yeast extract and observed using light microscopy and scanning electron microscopy. Samples for scanning electron microscopy were prepared as described previously (Itoh et al., 1989).

Cultural, physiological and biochemical characteristics. Cultural characteristics were tested by using $14 \mathrm{~d}$ cultures grown at $28^{\circ} \mathrm{C}$ on various agar media (Table 1). The Color Harmony Manual (Jacobson et al., 1958) was used for determining colour designations and names of colonies. The decomposition of various compounds was examined by using the basal media recommended by Gordon et al. (1974). The utilization of carbohydrates as sole carbon sources was tested with a neutralized yeast nitrogen base without amino acids (Difco) as a basal medium, according to the method of Stevenson (1967). The utilization of organic acids was examined on the defined medium of Gordon et al. (1974) supplemented with the vitamin B complex solution used in humic acid/vitamin agar. The reduction of nitrate was examined in nutrient broth (Difco) supplemented with $0.1 \%$ $(\mathrm{w} / \mathrm{v}) \mathrm{KNO}_{3}$. After cultivation of each organism at an optimal temperature, the resulting nitrite was detected as described by Gottlieb (1961). The requirements for vitamins (each at a concentration of $0.5 \mu \mathrm{g} \mathrm{ml}^{-1}$ ) were examined as described previously (Kudo et al., 1993). Tolerance of sodium chloride and changes in growth temperature were determined on modified Bennett's agar containing sucrose instead of glucose.

Chemotaxonomy. Freeze-dried cells required for chemotaxonomic analysis were obtained from cultures grown in yeast extract/glucose broth (containing $10 \mathrm{~g}$ yeast extract and $10 \mathrm{~g}$ $\mathrm{D}$-glucose in $1000 \mathrm{ml}$ distilled water; $\mathrm{pH} \mathrm{7.2)} \mathrm{on} \mathrm{a} \mathrm{rotary}$ shaker at an optimal temperature for each organism. Cellwall peptidoglycan was prepared and hydrolysed by the methods of Kawamoto et al. (1981) and the amino acid composition was analysed using an automatic amino acid analyser. The isomers of diaminopimelic acid $\left(A_{2} \mathrm{pm}\right)$ in cell walls were determined using the method of Staneck \& Roberts (1974), and reducing sugars from whole-cell hydrolysates were analysed using the HPLC method of Mikami \& Ishida (1983). The acyl group of muramic acid in peptidoglycan was determined using the method of Uchida \& Aida (1984). Phospholipids in cells were extracted and identified using the method of Minnikin et al. (1984). Methyl esters of cellular fatty acids were prepared by means of the direct transmethylation method with methanolic hydrochloride (Suzuki \& Komagata, 1983) and were analysed by using GLC as described previously (Kudo et al., 1993). The identification of each peak was carried out by comparison with commercially available standards and by using GCMS. Isoprenoid quinones were extracted according to the method of Collins et al. (1977) and were analysed by HPLC with a Cosmosil $5 \mathrm{C}_{18}$ column $(4.6 \times 150 \mathrm{~mm}$; Nacalai Tesque). The elution solvent was a mixture of methanol and 2-propanol $(2: 1, \mathrm{v} / \mathrm{v})$.

16S rDNA sequence analysis. The $16 \mathrm{~S}$ rDNA was amplified using the PCR method with a Taq DNA polymerase

Table 1. Cultural characteristics of strains DF- $32^{\top}$ and DF-28

Colour numbers and names (in parentheses) were taken from the Color Harmony Manual (Jacobson et al., 1958).

\begin{tabular}{|c|c|c|c|c|c|c|}
\hline \multirow[t]{2}{*}{ Medium } & \multicolumn{3}{|c|}{ Strain DF-32 } & \multicolumn{3}{|c|}{ Strain DF-28 } \\
\hline & Growth and colour & Aerial mycelium and colour & $\begin{array}{l}\text { Soluble } \\
\text { pigment }\end{array}$ & Growth and colour & $\begin{array}{l}\text { Aerial mycelium and } \\
\text { colour }\end{array}$ & $\begin{array}{l}\text { Soluble } \\
\text { pigment }\end{array}$ \\
\hline $\begin{array}{l}\text { Nonomura's yeast } \\
\text { extract/starch agar }\end{array}$ & Good (dark lacquer red, 6 pe) & Poor (shell pink, 6 ca) & Yellow & Good (dark lacquer red, $6 \mathrm{pe}$ ) & Poor (shell pink, $6 \mathrm{ca}$ ) & Yellow \\
\hline Oatmeal agar & Good (persimmon, $5 \mathrm{nc}$ ) & Poor (pink tint, 7 ba) & Yellow & Good (bright peach, $5 \mathrm{ia}$ ) & Poor (pink tint, 7 ba) & Yellow \\
\hline $\begin{array}{l}\text { Oatmeal agar }+1 \% \text { yeast } \\
\text { extract }\end{array}$ & Good (light coral pink, 6 la) & Good (pale pink, $7 \mathrm{ca}$ ) & None & Good (coral, 6 lc) & Good (pale pink, $7 \mathrm{ca}$ ) & None \\
\hline $\begin{array}{l}\text { Inorganic salts } / \text { starch } \\
\text { agar }+1 \% \text { yeast extract }\end{array}$ & Good (coral, $6 \mathrm{lc}$ ) & Good (cherry pink, 7 ea) & None & Good (shrimp pink, $61 / 2$ ia) & Good (pale pink, $7 \mathrm{ca}$ ) & None \\
\hline $\begin{array}{l}\text { Modified Bennett's agar } \\
\text { containing sucrose }\end{array}$ & Good (barn red, $6 \mathrm{pg}$ ) & Poor (shell pink, $6 \mathrm{ca}$ ) & Yellow & Good (Venetian red, 6 pi) & Poor (shell pink, $6 \mathrm{ca}$ ) & Yellow \\
\hline Dilute $(1 / 20)$ V8 juice agar & Moderate (amber, 3 pc) & None & None & Moderate (russet orange, $4 \mathrm{pc}$ ) & None & None \\
\hline $\begin{array}{l}\text { Glucose/asparagine } \\
\text { agar }+1 \% \text { yeast extract }\end{array}$ & Good (russet, 5 pg) & Poor (pink tint, 7 ba) & Yellow & Good (russet, 5 pg) & None & Yellow \\
\hline $\begin{array}{l}\text { Yeast extract/malt extract } \\
\text { agar }\end{array}$ & Good (terracotta, 5 pe) & Moderate (shell pink, $6 \mathrm{ca}$ ) & None & Good (tile red, 5 ne) & Moderate (pale pink, $7 \mathrm{ca}$ ) & None \\
\hline Yeast extract/starch agar & Good (paprika, $6 \mathrm{pc}$ ) & Moderate (shell pink, $6 \mathrm{ca}$ ) & Yellow & Moderate (bitter sweet, $5 \mathrm{pc}$ ) & None & Yellow \\
\hline $\begin{array}{l}\text { Dilute }(1 / 5) \text { yeast } \\
\text { extract/starch agar }\end{array}$ & Moderate (persimmon, $5 \mathrm{lc}$ ) & None & Yellow & Moderate (persimmon, $5 \mathrm{nc}$ ) & None & Yellow \\
\hline
\end{tabular}


Microbispora corallina sp. nov.

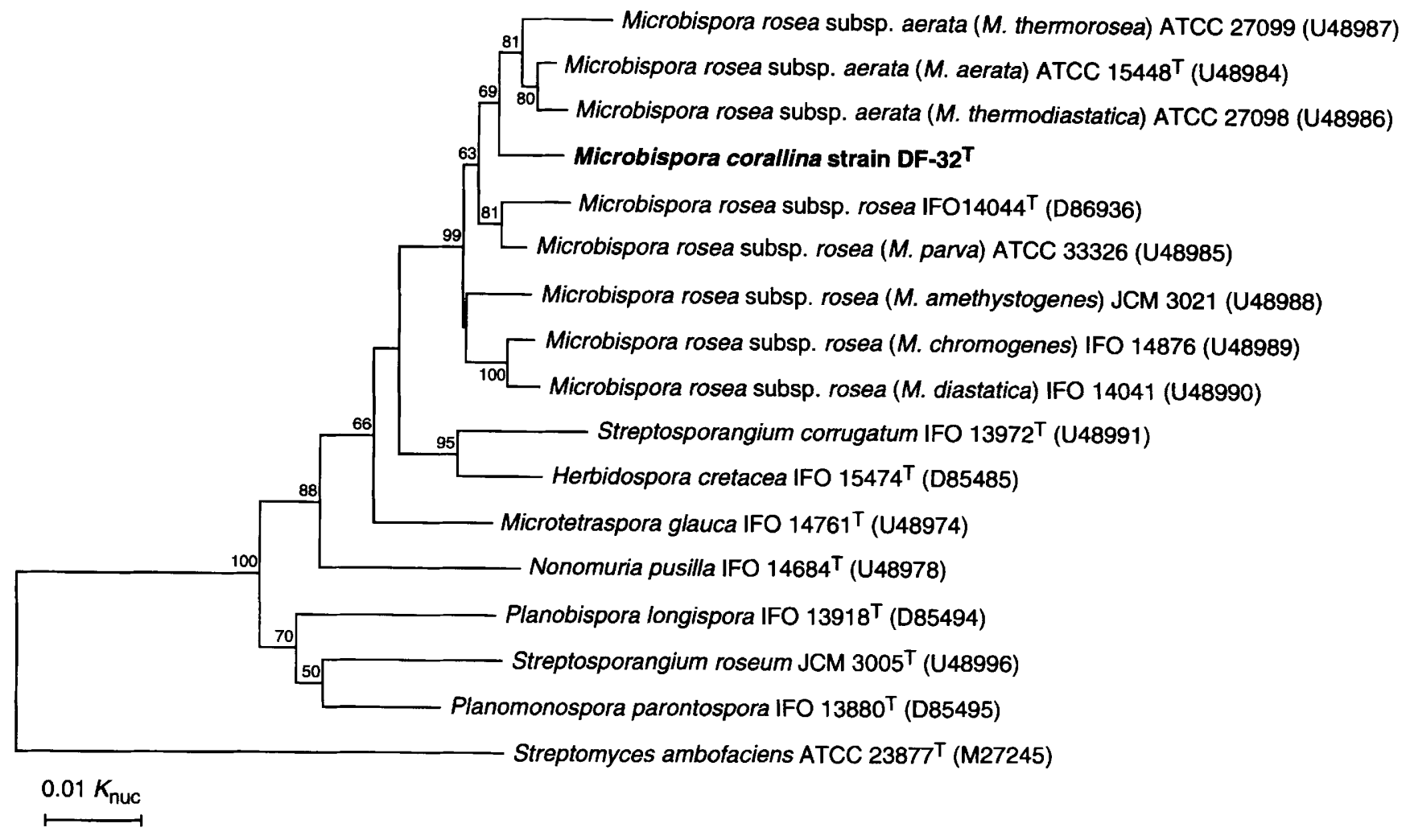

Fig. 1. 165 rDNA-based neighbour-joining tree showing the relationship between strain DF- $32^{\top}$ and Microbispora species and selected organisms belonging to the family Streptosporangiaceae. The numbers on the branches indicate the percentage bootstrap values of 1000 replicates (greater than $50 \%$ ). The scientific names in parentheses are the originally proposed names of the strains; the numbers in parentheses are the GenBank/EMBL/DDBJ database accession numbers.

(Takara) and primers 20F (positions 10-25, Escherichia coli numbering) and 1540R (1542-1525). Amplification was carried out using a DNA thermal cycler (GeneAmp PCR System 9700; Applied Biosystems) according to the following programme: $94^{\circ} \mathrm{C}$ for $5 \mathrm{~min}$ followed by 30 cycles of denaturation $\left(94^{\circ} \mathrm{C}\right.$ for $\left.1 \mathrm{~min}\right)$, primer annealing $\left(55^{\circ} \mathrm{C}\right.$ for $1.5 \mathrm{~min})$ and primer extension $\left(72^{\circ} \mathrm{C}\right.$ for $\left.2.5 \mathrm{~min}\right)$. At the end of the cycle, the reaction mixture was kept at $72{ }^{\circ} \mathrm{C}$ for $10 \mathrm{~min}$ and then cooled to $4^{\circ} \mathrm{C}$. The amplified $16 \mathrm{~S}$ rDNA fragment was purified and subjected directly to cycle sequencing using an ABI PRISM BigDye Terminator Cycle Sequencing Ready Reaction kit (Applied Biosystems), according to the manufacturer's protocol, with the following primers: $27 \mathrm{~F}, 11-27 ; 350 \mathrm{~F}, 343-357 ; 350 \mathrm{R}, 357-342 ; 780 \mathrm{~F}$, 786-803; 780R, 803-785; 1100F, 1099-1114; 1492R, 15101492. The conditions for thermal cycling were as follows: $96^{\circ} \mathrm{C}$ for $30 \mathrm{~s}$ followed by 25 cycles of denaturation $\left(96^{\circ} \mathrm{C}\right.$ for $10 \mathrm{~s})$, primer annealing $\left(50^{\circ} \mathrm{C}\right.$ for $\left.5 \mathrm{~s}\right)$ and primer extension $\left(60^{\circ} \mathrm{C}\right.$ for $\left.4 \mathrm{~min}\right)$. The products were analysed with an ABI PRISM 310 Genetic Analyser (Applied Biosystems). The sequence was multiply aligned with selected sequences (Fig. 1) obtained from the GenBank/EMBL/ DDBJ databases by using the CLUSTAL w program package (Thompson et al., 1994); the alignment was manually verified and adjusted prior to the construction of a phylogenetic tree. The phylogenetic tree was constructed using the neighbour-joining method (Saitou \& Nei, 1987) in the PHYLIP package (Felsenstein, 1995). The confidence values of branches of the phylogenetic tree were determined using bootstrap analyses (Felsenstein, 1985) based on 1000 re- samplings. The values for sequence similarity among Microbispora strains were calculated manually after pairwise alignments obtained using the CLUSTAL w package. Gaps and ambiguous nucleotides were eliminated from the calculations.

Preparation of DNA, DNA base composition and DNA-DNA hybridization. DNA was isolated from cells grown in yeast extract/glucose broth according to the method of Saito \& Miura (1963) but with a minor modification described previously (Kudo et al., 1998). The $G+C$ content of the DNA was determined using the HPLC method of Tamaoka \& Komagata (1984). An equimolar mixture of nucleotides for the analysis of DNA base composition (Yamasa Shoyu) was used as the quantitative standard. DNA-DNA relatedness was measured fluorometrically using the microplate hybridization method devised by Ezaki et al. (1989).

\section{RESULTS}

\section{Morphology}

Strains DF-28 and DF- $32^{\mathrm{T}}$ produced branched and unfragmented substrate mycelia and monopodially branching aerial mycelia. The aerial hyphae bore nonmotile spores on short sporophores in characteristic longitudinal pairs (Fig. 2). The sporophores with paired spores were usually branched alternately from the main hypha. Each spore was oval and its surface 


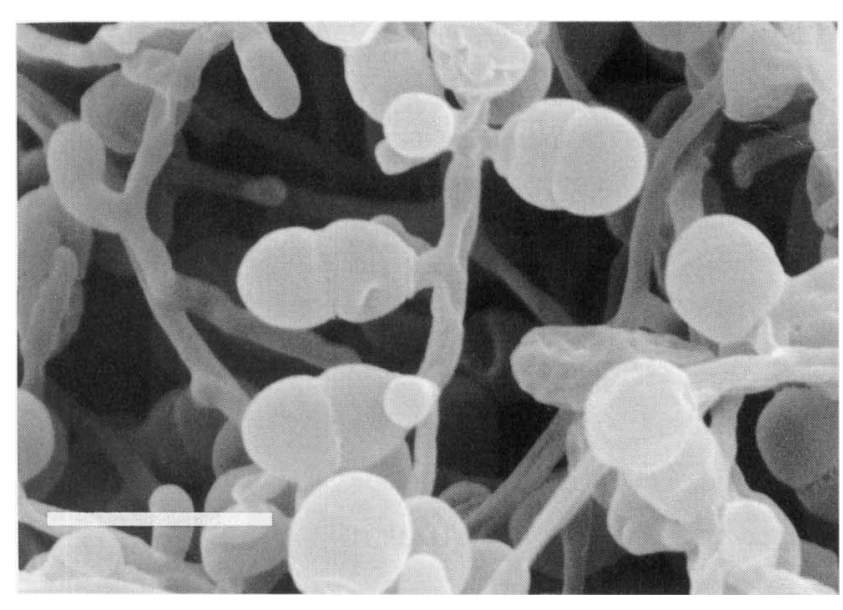

Fig. 2. Scanning electron micrograph of strain DF-28 grown on inorganic salts/starch agar (ISP medium no. 4) supplemented with $1 \%$ yeast extract for $14 \mathrm{~d}$ at $28^{\circ} \mathrm{C}$. Bar, $2 \mu \mathrm{m}$. was smooth. Neither sporangium-like bodies nor any other special structures were observed.

\section{Cultural, physiological and biochemical characteristics}

The cultural characteristics of our isolates are shown in Table 1. The substrate mycelium of both strains on most media tested was pinkish to brownish red. When produced, the aerial mycelium was pink. Yellowish, soluble pigments were produced in several media. Table 2 summarizes the results of physiological and biochemical testing of our isolates and strains used for comparison.

\section{Chemotaxonomic properties}

The chemotaxonomic features of our isolates were alike and were also similar to those of members of the family Streptosporangiaceae. The cell wall peptido-

Table 2. Physiological and biochemical characteristics differentiating the isolates from authentic strains of the genus Microbispora

Glyc., Glycerol; myo-Inos., myo-inositol; D-Sorb., D-sorbitol; Hypox., hypoxanthine; Testost., testosterone.

\begin{tabular}{|c|c|c|c|c|c|c|c|c|c|c|c|c|c|c|c|}
\hline \multicolumn{2}{|l|}{ Organism } & \multicolumn{3}{|c|}{ Growth at: } & \multicolumn{3}{|c|}{ Utilization of: } & \multicolumn{2}{|c|}{ Decomposition of: } & \multicolumn{2}{|c|}{ Utilization of: } & \multicolumn{2}{|c|}{ Requirement for: } & \multirow{2}{*}{$\begin{array}{c}\text { Reduc- } \\
\text { tion } \\
\text { of nitrate }\end{array}$} & \multirow{2}{*}{$\begin{array}{l}\text { Produc- } \\
\text { tion } \\
\text { of iodinin }\end{array}$} \\
\hline Current name and strain & Original name & $17^{\circ} \mathrm{C}$ & $25^{\circ} \mathrm{C}$ & $55^{\circ} \mathrm{C}$ & Glyc. & $\begin{array}{l}\text { myo- } \\
\text { Inos. }\end{array}$ & D-Sorb. & Hypox. & Testost. & Lactate & Malate & Biotin & Thiamine & & \\
\hline \multicolumn{16}{|l|}{ Isolate } \\
\hline DF -28 & & + & + & - & ++ & ++ & + & + & - & - & + & - & + & + & - \\
\hline $\mathrm{DF}-32^{\mathrm{T}}$ & & + & + & - & ++ & ++ & + & - & - & + & - & - & + & + & - \\
\hline \multicolumn{16}{|l|}{ M. rosea subsp. rosea } \\
\hline $\mathrm{JCM} 3006^{\mathrm{T}}$ & $M$. rosea & + & + & - & - & - & \pm & + & + & + & + & + & + & ++ & - \\
\hline JCM 8971 & $M$. indica & + & + & - & + & - & + & + & + & + & + & + & + & ++ & - \\
\hline JCM 3022 & M. chromogenes & + & + & - & ++ & + & ++ & + & + & + & - & + & + & ++ & - \\
\hline JCM 3023 & $M$. diastatica & + & + & - & ++ & + & ++ & + & + & + & - & - & - & ++ & - \\
\hline JCM 8972 & M. karnatakensis & + & + & - & + & \pm & + & + & + & + & + & - & + & ++ & - \\
\hline JCM 3024 & M. parva & + & + & - & ++ & - & \pm & - & + & + & + & - & + & - & + \\
\hline JCM 3021 & M. amethystogenes & + & + & - & - & - & - & - & - & + & - & - & + & ++ & + \\
\hline \multicolumn{16}{|l|}{ M. rosea subsp. aerata } \\
\hline JCM $3076^{\mathrm{T}}$ & M. aerata & - & + & + & \pm & \pm & \pm & - & - & \pm & + & + & + & ++ & + \\
\hline JCM 3110 & M. thermodiastatica & - & - & + & \pm & - & + & + & + & - & - & + & + & - & - \\
\hline JCM 3111 & M. thermorosea & - & - & + & + & - & + & + & + & - & + & + & + & - & - \\
\hline \multicolumn{16}{|l|}{ Microbispora sp. } \\
\hline JCM 3298 & $\begin{array}{c}\text { 'M. rosea subsp. } \\
\text { nonnitritogenes' }\end{array}$ & + & + & - & - & - & \pm & + & + & + & - & + & + & - & - \\
\hline JCM 10122 & $\begin{array}{l}\text { 'M. amethystogenes subsp. } \\
\text { nonreducans' }\end{array}$ & + & + & - & - & - & - & - & - & - & - & - & + & + & + \\
\hline
\end{tabular}

Table 3. Cellular fatty acid compositions of the isolates and the type strain of $M$. rosea subsp. rosea TR, Trace amount $(<0.5 \%)$.

\begin{tabular}{|c|c|c|c|c|c|c|c|c|c|c|c|c|c|c|c|c|c|c|c|c|c|}
\hline \multirow[t]{3}{*}{ Strain } & \multicolumn{21}{|c|}{ Fatty acid composition (\%) } \\
\hline & \multicolumn{9}{|c|}{ Normal } & \multicolumn{7}{|c|}{ Iso } & \multicolumn{2}{|c|}{ Anteiso } & \multicolumn{3}{|c|}{ 10-Methyl } \\
\hline & $13: 0$ & $14: 0$ & $15: 0$ & $16: 0$ & $16: 1$ & $17: 0$ & $17: 1$ & $18: 0$ & 18:1 & $14: 0$ & $15: 0$ & $16: 0$ & $16: 1$ & $17: 0$ & $18: 0$ & $18: 1$ & $15: 0$ & $17: 0$ & $\begin{array}{c}10-\mathrm{Me}- \\
16: 0\end{array}$ & $\begin{array}{c}\text { 10-Me- } \\
17: 0\end{array}$ & $\begin{array}{c}\text { 10-Me- } \\
18: 0\end{array}$ \\
\hline \multicolumn{22}{|l|}{ Isolate } \\
\hline DF $-32^{\mathrm{T}}$ & $\mathrm{TR}$ & 1 & 10 & 8 & 2 & 9 & 6 & 1 & 1 & 2 & 7 & 19 & & 2 & 1 & & 3 & 3 & 4 & 17 & 2 \\
\hline $\mathrm{DF}-28$ & TR & 1 & 3 & 14 & 1 & 20 & 1 & 10 & 1 & 1 & 2 & 13 & & 3 & 2 & & 3 & 7 & 2 & 10 & 6 \\
\hline $\begin{array}{l}\text { Microbispora rosea subsp. } \\
\text { rosea JCM } 3006^{\mathrm{T}}\end{array}$ & $\mathrm{TR}$ & 1 & 5 & 8 & 1 & 19 & 3 & 3 & 1 & $\mathrm{TR}$ & 3 & 26 & TR & 3 & 2 & $T R$ & 1 & 4 & 3 & 11 & 2 \\
\hline
\end{tabular}


Microbispora corallina sp. nov.

Table 4. Levels of DNA-DNA relatedness among the isolates and authentic strains of the genus Microbispora

\begin{tabular}{|c|c|c|c|c|c|c|c|c|c|c|c|c|c|c|c|c|}
\hline \multirow{2}{*}{$\frac{\text { Organism }}{\text { Current name and strain }}$} & \multirow[b]{2}{*}{ Original name } & \multirow{2}{*}{$\begin{array}{c}\mathbf{G}+\mathbf{C} \text { content } \\
(\mathrm{mol} \%)\end{array}$} & \multicolumn{14}{|c|}{ Percentage DNA complementarity with labelled DNA from: } \\
\hline & & & DF-32 ${ }^{\mathrm{T}}$ & DF-28 & $\begin{array}{l}\mathrm{JCM} \\
3006^{\mathrm{T}}\end{array}$ & $\begin{array}{r}J C M \\
8971\end{array}$ & $\begin{array}{r}\text { JCM } \\
3022\end{array}$ & $\begin{array}{r}\text { JCM } \\
3023\end{array}$ & $\begin{array}{r}\text { JCM } \\
8972\end{array}$ & $\begin{array}{r}\text { JCM } \\
3024\end{array}$ & $\begin{array}{r}\text { JCM } \\
3298\end{array}$ & $\begin{array}{l}\text { JCM } \\
3076^{\prime}\end{array}$ & $\begin{array}{r}\text { JCM } \\
3110\end{array}$ & $\begin{array}{r}\mathrm{JCM} \\
3111\end{array}$ & $\begin{array}{r}\mathbf{J C M} \\
\mathbf{3 0 2 1}\end{array}$ & $\begin{array}{l}\text { JCM } \\
10122\end{array}$ \\
\hline \multicolumn{17}{|l|}{ Isolate } \\
\hline DF $-32^{\mathrm{T}}$ & & $71 \cdot 5$ & 100 & 99 & 34 & 32 & 37 & 37 & 31 & 31 & 32 & 31 & 32 & 32 & 31 & 36 \\
\hline DF-28 & & $71 \cdot 2$ & 93 & 100 & 32 & 31 & 35 & 36 & 32 & 30 & 31 & 31 & 32 & 32 & 32 & 36 \\
\hline \multicolumn{17}{|l|}{ M. rosea subsp. rosea } \\
\hline $\mathrm{JCM} 3006^{\mathrm{T}}$ & M. rosea & $69 \cdot 9$ & 45 & 33 & 100 & 112 & 75 & 74 & 65 & 66 & 62 & 71 & 58 & 56 & 53 & 53 \\
\hline JCM 8971 & $M$. indica & $70 \cdot 0$ & 41 & 35 & 93 & 100 & 72 & 76 & 66 & 75 & 63 & 63 & 55 & 57 & 48 & 52 \\
\hline JCM 3022 & M. chromogenes & $70 \cdot 0$ & 35 & 32 & 73 & 70 & 100 & 80 & 67 & 61 & 58 & 60 & 55 & 56 & 50 & 49 \\
\hline JCM 3023 & $M$. diastatica & $68 \cdot 9$ & 34 & 29 & 73 & 69 & 85 & 100 & 68 & 60 & 53 & 55 & 56 & 55 & 49 & 52 \\
\hline JCM 8972 & M. karnatakensis & $70 \cdot 4$ & 36 & 32 & 70 & 65 & 77 & 78 & 100 & 61 & 60 & 63 & 56 & 57 & 52 & 53 \\
\hline JCM 3024 & M. parva & $69 \cdot 8$ & 31 & 27 & 68 & 65 & 61 & 60 & 57 & 100 & 54 & 52 & 51 & 52 & 41 & 46 \\
\hline Microbispora sp. JCM 3298 & $\begin{array}{l}\text { 'M. rosea subsp. } \\
\text { nonnitritogenes' }\end{array}$ & $70 \cdot 2$ & 41 & 30 & 64 & 61 & 61 & 63 & 58 & 51 & 100 & 69 & 57 & 54 & 55 & 54 \\
\hline \multicolumn{17}{|l|}{$M$. rosea subsp. aerata } \\
\hline JCM $3076^{\mathrm{T}}$ & M. aerata & $70 \cdot 8$ & 35 & 33 & 62 & 59 & 62 & 62 & 58 & 60 & 58 & 100 & 80 & 69 & 47 & 52 \\
\hline JCM 3110 & M. thermodiastatica & $70 \cdot 3$ & 32 & 31 & 58 & 56 & 60 & 58 & 55 & 55 & 55 & 79 & 100 & 69 & 46 & 50 \\
\hline JCM 3111 & M. thermorosea & $70-1$ & 35 & 33 & 61 & 59 & 61 & 60 & 6] & 58 & 59 & 68 & 69 & 100 & 44 & 51 \\
\hline M. rosea subsp. rosea JCM 3021 & $M$. amethystogenes & $70 \cdot 5$ & 34 & 30 & 49 & 47 & 50 & 48 & 44 & 41 & 48 & 51 & 44 & 43 & 100 & 81 \\
\hline Microbispora sp. JCM 10122 & $\begin{array}{l}\text { 'M. amethystogenes subsp. } \\
\text { nonreducans' }\end{array}$ & $70 \cdot 2$ & 32 & 29 & 47 & 44 & 51 & 50 & 46 & 43 & 46 & 46 & 44 & 43 & 71 & 100 \\
\hline
\end{tabular}

glycan of our isolates contained glutamic acid, alanine and $\mathrm{A}_{2} \mathrm{pm}$ in a molar ratio of $1 \cdot 0: 1 \cdot 3: 0 \cdot 9$ (calculated by defining the amount of glutamic acid as 1.0); an isomer of $\mathrm{A}_{2} \mathrm{pm}$ was in the meso-form. These data indicate that their cell wall type (Lechevalier \& Lechevalier, 1970) and their peptidoglycan type (Schleifer \& Kandler, 1972) are type IIII and type A $1 \gamma$, respectively. The $N$-acyl group of muramic acid in the peptidoglycan was of the acetyl type. Glucose, mannose, ribose and a trace amount of madurose (3- $O$-methylD-galactose) were detected as whole-cell sugars, but galactose, arabinose, xylose and rhamnose were not [whole-cell sugar pattern B of Lechevalier \& Lechevalier (1970)]. The polar lipid profile was characterized by the presence of phosphatidylethanolamine and ninhydrin-positive glycophospholipids. This result suggests that the phospholipid pattern is type PIV of Lechevalier et al. (1977). The cellular fatty acid compositions of our isolates and $M$. rosea subsp. rosea JCM $3006^{\mathrm{T}}$ are shown in Table 3 . These organisms all contained hexadecanoic $(n-16: 0)$, heptadecanoic ( $n$ 17:0), 14-methylpentadecanoic $(i-16: 0)$ and 10methylheptadecanoic (10-Me-17:0) acids as major components. The predominant menaquinones were MK-9(III,VIII- $\left.\mathrm{H}_{4}\right)$, MK-9 $\left(\mathrm{H}_{2}\right)$ and MK-9 $\left(\mathrm{H}_{0}\right)$. The $\mathrm{G}+\mathrm{C}$ content of the DNA from the isolates was 71-72 $\mathrm{mol} \%$ (Table 4 ).

\section{5 rDNA sequence}

The almost complete 16S rDNA sequence of our isolate (strain DF-32 ${ }^{\mathrm{T}}$ ), consisting of 1442 nucleotides, was compared with sequences from members of the genus Microbispora and the other strains selected from the family Streptosporangiaceae (Fig. 1). The data-set used for constructing the phylogenetic tree contained 1379 nucleotide positions for each sequence as a result of the elimination of gaps and ambiguous nucleotides from the sequences between positions 57 and 1491 ( $E$. coli position numbers). As shown in Fig. 1, members of the genus Microbispora formed a coherent cluster and the phylogenetic position of strain DF- $32^{\mathrm{T}}$ was entirely located within this cluster. The levels of $16 \mathrm{~S}$ rDNA sequence similarity between strain DF- $32^{\mathrm{T}}$ and other members of the genus Microbispora ranged from 97.3 to $98.4 \%$, whereas the level between this strain and $T$. bispora ATCC $19993^{\mathrm{T}}$ (GenBank accession no. U58523) was $92.0 \%$.

\section{DNA-DNA hybridization}

Table 4 shows results of DNA-DNA hybridization experiments among our isolates and Microbispora species. The levels of DNA relatedness between strains DF-28 and DF-32 $2^{\mathrm{T}}$ were $93-99 \%$, whereas these isolates exhibited only $27-45 \%$ DNA relatedness to previously described Microbispora species. However, values of DNA relatedness among strains currently designated as $M$. rosea, except for two strains originally named $M$. amethystogenes, ranged from $51 \%$ to approximately $100 \%$ (mean $67 \%$ ). M. amethystogenes JCM 3021 and ' $M$. amethystogenes subsp. nonreducans' JCM 10122 exhibited high levels of DNA relatedness (more than $71 \%$ ) to each other, but exhibited only $41-55 \%$ DNA relatedness (mean $48 \%$ ) to other $M$. rosea strains.

\section{DISCUSSION}

Both strains, DF-28 and DF-32 ${ }^{\mathrm{T}}$, showed morphological and chemotaxonomic features peculiar to the genera Microbispora (Kroppenstedt et al., 1990; Miyadoh et al., 1990) and Thermobispora (Wang et al., 1996b). Although it is difficult to distinguish these two genera phenotypically, the phylogenetic analysis indicated that one of our isolates (strain DF- $32^{\mathrm{T}}$ ) should 
be classified as a member of the genus Microbispora (Fig. 1).

Comparisons with the descriptions of previously characterized species of the genus Microbispora show that the morphological features of our isolates are obviously different from those of M. mesophila, which forms a single spore on each sporophore and was recently transferred from the genus Thermomonospora (Zhang et al., 1998). We compared our isolates with all of the remaining species in terms of physiological and biochemical properties and DNA-DNA reassociation. Both strains, DF-28 and DF-32 ${ }^{\mathrm{T}}$, showed a similar pattern in physiological and biochemical tests (Table 2). As our isolates could not grow at $50{ }^{\circ} \mathrm{C}$, they were clearly distinguishable from the thermophilic strains belonging to $M$. rosea subsp. aerata (previously described as $M$. aerata, $M$. thermorosea and $M$. thermodiastatica), all of which showed good growth at $55^{\circ} \mathrm{C}$. The isolates were also distinguishable from the remaining mesophilic strains belonging to $M$. rosea subsp. rosea (including the invalidly proposed subspecies ' $M$. rosea subsp. nonnitritogenes' and ' $M$. amethystogenes subsp. nonreducans') by a combination of biochemical properties, in particular the utilization of myo-inositol and the decomposition of testosterone, as shown in Table 2. In the DNA-DNA hybridization experiments, our isolates exhibited high levels of relatedness to each other $(93-99 \%)$, whereas values for relatedness between the isolates and all of the strains used for comparison were only $45 \%$ or less (Table 4). Consequently, we propose a new species, Microbispora corallina, to accommodate the two strains DF-32 ${ }^{\mathrm{T}}\left(=\mathrm{JCM} 10267^{\mathrm{T}}\right)$ and DF-28 $(=\mathrm{JCM}$ 10266).

The results of our DNA-DNA hybridization experiments also provided information regarding the intrageneric classification of the genus Microbispora. Miyadoh et al. (1990) combined 10 species of this genus into a single species, $M$. rosea, on the basis of DNA relatedness. However, Wang et al. (1996a) doubted this conclusion for the following reasons: none of the similarity values for $16 \mathrm{~S}$ rDNA sequences among $M$. rosea strains calculated by Wang et al. exceeded $97 \%$, and 58 of the 90 DNA reassociation values obtained for the 10 strains were less than $60 \%$. We recalculated the sequence-similarity values for sequences from Microbispora species obtained in this study and from GenBank/EMBL/DDBJ sequence databases. As a result, the sequence-similarity values among the members classified in $M$. rosea ranged from 97.0 to $99.6 \%$; these results imply that species definition within the genus Microbispora should be based on DNA-DNA reassociation results according to the principle of Stackebrandt \& Goebel (1994). Certainly, the results of Miyadoh et al. (1990) and this study produced homology values of less than $60 \%$ among strains of redefined $M$. rosea; this may be correlated to heterogeneity of their phenotypic characteristics. In our results, if strains JCM 3021 ( $M$. amethystogenes) and JCM 10122 ('M. amethystogenes subsp. nonreducans') are excluded, the values for DNA relatedness within each subspecies $(M$. rosea subsp. rosea or $M$. rosea subsp. aerata) and between the subspecies were greater than 57 and $51 \%$, respectively. These values are thought to be rather low for considering them as a single species, but it is also the case that we cannot delineate the species because of the continuity of these values. However, $M$. amethystogenes and the informally proposed ' $M$. amethystogenes subsp. nonreducans' should be placed in an independent species because of the significantly low values of DNA relatedness with other $M$. rosea strains (41-55\%, mean 48\%). 'M. amethystogenes subsp. nonreducans' does not merit designation as an independent subspecies of $M$. amethystogenes because of the high values of DNA relatedness between the two strains (71-81\%) (Table 4) and the almost identical pattern of their physiological and biochemical characteristics (Table 2).

\section{Description of Microbispora corallina sp. nov.}

Microbispora corallina (co.ral'li.na. L. fem. adj. corallina coral-coloured).

Substrate mycelia are coral pink to reddish brown and aerial mycelia are pink on most agar media. Either no pigments or faint, yellow, soluble pigments are produced. Spores arranged in longitudinal pairs are formed on short sporophores alternately branched from aerial hyphae. Spores are oval and have smooth surfaces. Decomposes casein and aesculin, but not adenine, elastin, guanine, hypoxanthine, keratin, testosterone, L-tyrosine, xanthine, xylan or DNA. Utilizes amygdalin, L-arabinose, arbutin, D-cellobiose, D-fructose, D-galactose, D-glucose, glycerol, $m y o$-inositol, Dlactose, maltose, D-mannitol, D-mannose, D-melezitose, D-melibiose, methyl $\alpha$-D-glucoside, D-ribose, salicin, D-sorbitol, L-sorbose, starch, sucrose, D-trehalose and D-xylose as sole carbon sources, but not adonitol, D-arabitol, dulcitol, iso-erythritol, inulin, D-raffinose, L-rhamnose or xylitol. Utilizes fumaric acid and succinic acid, but not benzoic acid, citric acid, mucic acid, oxalic acid or L-tartaric acid. Negative for iodinin production. Reduces nitrate to nitrite. No growth occurs in the presence of $3 \% \mathrm{NaCl}$. Requires thiamine for growth. Mesophilic. The $\mathrm{G}+\mathrm{C}$ content of the DNA ranges from 71 to $72 \mathrm{~mol} \%$. The type strain is strain DF-32 $2^{\mathrm{T}}\left(=\mathrm{JCM} 10267^{\mathrm{T}}\right)$.

\section{ACKNOWLEDGEMENTS}

We thank M. Chijimatsu, Division of Biomolecular Characterization, The Institute of Physical and Chemical Research (RIKEN), for analysing the amono acid composition of peptidoglycan.

\section{REFERENCES}

Collins, M. D., Pirouz, T., Goodfellow, M. \& Minnikin, D. E. (1977). Distribution of menaquinones in actinomycetes and corynebacteria. J Gen Microbiol 100, 221-230. 
Ezaki, T., Hashimoto, Y. \& Yabuuchi, E. (1989). Fluorometric deoxyribonucleic acid-deoxyribonucleic acid hybridization in microdilution wells as an alternative to membrane filter hybridization in which radioisotopes are used to determine genetic relatedness among bacterial strains. Int J Syst Bacteriol 39, 224-229.

Felsenstein, J. (1985). Confidence limits on phylogenies: an approach using the bootstrap. Evolution 39, 783-791.

Felsenstein, J. (1995). PHYLIP (phylogenetic inference package), version $3.57 \mathrm{c}$. Department of Genetics, University of Washington, Seattle, USA.

Gordon, R. E., Barnett, D. A., Handerhan, J. E. \& Pang, C. H.-N. (1974). Nocardia coeliaca, Nocardia autotrophica, and the nocardin strain. Int $J$ Syst Bacteriol 24, 54-63.

Gottlieb, D. (1961). An evaluation of criteria and procedures used in the description and characterization of the streptomycetes. Appl Microbiol 9, 55-65.

Hayakawa, M. \& Nonomura, H. (1987). Humic acid-vitamin agar, a new medium for the selective isolation of soil actinomycetes. J Ferment Technol 65, 501-509.

Itoh, T., Kudo, T., Parenti, F. \& Seino, A. (1989). Amended description of the genus Kineosporia, based on chemotaxonomic and morphological studies. Int J Syst Bacteriol 39, 168-173.

Jacobson, E., Grauville, W. C. \& Fogs, C. E. (1958). Color Harmony Manual, 4th edn. Chicago: Container Corporation of America.

Kawamoto, I., Oka, T. \& Nara, T. (1981). Cell wall composition of Micromonospora olivoasterospora, Micromonospora sagamiensis, and related organisms. J Bacteriol 146, 527-534.

Kroppenstedt, R. M., Stackebrandt, E. \& Goodfellow, M. (1990). Taxonomic revision of the actinomycete genera Actinomadura and Microtetraspora. Syst Appl Microbiol 13, 148-160.

Kudo, T., Itoh, T., Miyadoh, S., Shomura, T. \& Seino, A. (1993). Herbidospora gen. nov., a new genus of the family Streptosporangiaceae Goodfellow et al. 1990. Int J Syst Bacteriol 43, 319-328.

Kudo, T., Matsushima, K., Itoh, T., Sasaki, J. \& Suzuki, K. (1998). Description of four new species of the genus Kineosporia: Kineosporia succinea sp. nov., Kineosporia rhizophila sp. nov., Kineosporia mikuniensis sp. nov. and Kineosporia rhamnosa sp. nov., isolated from plant samples, and amended description of the genus Kineosporia. Int J Syst Bacteriol 48, 1245-1255.

Lechevalier, M. P. \& Lechevalier, H. (1970). Chemical composition as a criterion in the classification of aerobic actinomycetes. Int J Syst Bacteriol 20, 435-443.

Lechevalier, M. P., De Bievre, C. \& Lechevalier, H. (1977). Chemotaxonomy of aerobic actinomycetes: phospholipid composition. Biochem Syst Ecol 5, 249-260.

Mikami, H. \& Ishida, Y. (1983). Post-column fluorometric detection of reducing sugars in high-performance liquid chromatography using arginine. Bunseki Kagaku 32, E207-E210.

Minnikin, D. E., O’Donnell, A. G., Goodfellow, M., Alderson, G., Athalye, M., Schaal, A. \& Parlett, J. H. (1984). An integrated procedure for the extraction of bacterial isoprenoid quinones and polar lipids. J Microbiol Methods 2, 233-241.

Miyadoh, S., Tohyama, H., Amano, S., Shomura, T. \& Niida, T. (1985). Microbispora viridis, a new species of Actinomycetales. Int J Syst Bacteriol 35, 281-284.
Miyadoh, S., Amano, S., Tohyama, H. \& Shomura, T. (1990). A taxonomic review of the genus Microbispora and a proposal to transfer two species to the genus Actinomadura and to combine ten species into Microbispora rosea. J Gen Microbiol 136, 1905-1913.

Nonomura, H. \& Ohara, Y. (1957). Distribution of actinomycetes in soil. II. Microbispora, a new genus of the Streptomycetaceae. $J$ Ferment Technol 35, 307-311.

Rao, V. A., Prabhu, K. K., Sridhar, B. P., Venkateswarlu, A. \& Actor, P. (1987). Two new species of Microbispora from Indian soils: Microbispora karnatakensis sp. nov. and Microbispora indica sp. nov. Int J Syst Bacteriol 37, 181-185.

Saito, H. \& Miura, K. (1963). Preparation of transforming deoxyribonucleic acid by phenol treatment. Biochim Biophys Acta 72, 619-629.

Saitou, N. \& Nei, M. (1987). The neighbor-joining method: a new method for reconstructing phylogenetic trees. Mol Biol Evol 4, 406-425.

Schleifer, K. H. \& Kandler, O. (1972). Peptidoglycan types of bacterial cell walls and their taxonomic implications. Bacteriol Rev 36, 407-477.

Skerman, V. B. D., McGowan, V. \& Sneath, P. H. A. (1980). Approved lists of bacterial names. Int $J$ Syst Bacteriol 30, $225-420$.

Stackebrandt, E. \& Goebel, B. M. (1994). Taxonomic note: a place for DNA-DNA reassociation and 16S rRNA sequence analysis in the present species definition in bacteriology. Int $J$ Syst Bacteriol 44, 846-849.

Staneck, J. L. \& Roberts, G. D. (1974). Simplified approach to identification of aerobic actinomycetes by thin-layer chromatography. Appl Microbiol 28, 226-231.

Stevenson, I. L. (1967). Utilization of aromatic hydrocarbons by Arthrobacter spp. Can J Microbiol 13, 205-211.

Suzuki, K. \& Komagata, K. (1983). Taxonomic significance of cellular fatty acid composition in some coryneform bacteria. Int $J$ Syst Bacteriol 33, 188-200.

Tamaoka, J. \& Komagata, K. (1984). Determination of DNA base composition by reversed-phase high-performance liquid chromatography. FEMS Microbiol Lett 25, 125-128.

Thompson, J. D., Higgins, D. G. \& Gobson, T. J. (1994). CLUSTAL $\mathrm{W}$ : improving the sensitivity of progressive multiple sequence alignment through sequence weighting, position specific gap penalties and weight matrix choice. Nucleic Acids Res 22, 4673-4680.

Uchida, K. \& Aida, K. (1984). An improved method for the glycolate test for simple identification of the acyl type of bacterial cell walls. J Gen Appl Microbiol 30, 131-134.

Wang, Y., Zhang, Z. \& Ruan, J. (1996a). Phylogenetic analysis reveals new relationships among members of the genera Microtetraspora and Microbispora. Int J Syst Bacteriol 46, 658-663.

Wang, Y., Zhang, Z. \& Ruan, J. (1996b). A proposal to transfer Microbispora bispora (Lechevalier 1965) to a new genus, Thermobispora gen. nov., as Thermobispora bispora comb. nov. Int $J$ Syst Bacteriol 46, 933-938.

Zhang, Z., Wang, Y. \& Ruan, J. (1998). Reclassification of Thermomonospora and Microtetraspora. Int J Syst Bacteriol $\mathbf{4 8}$, 411-422. 